\title{
Predictors of crop diversification: a survey of tobacco farmers in North Carolina (USA)
}

\author{
David G Altman, Daniel J Zaccaro, Douglas W Levine, David Austin, Carol Woodell, \\ Betty Bailey, Michael Sligh, Gerry Cohn, James Dunn
}

\begin{abstract}
Objective-To assess the attitudes and behaviours of North Carolina tobacco farmers around crop diversification. Design-Cross-sectional telephone survey.

Participants-Active tobacco farmers in 14 North Carolina counties $(n=1236)$, interviewed between January and April 1997 (91\% response rate).

Outcome measures-Interest in, experience with, and perceived barriers to diversification.
\end{abstract}

Results-Most farmers (95\%) grew/raised a commodity other than tobacco (mean = 2.8 ). A total of $60 \%$ of farmers expressed interest in trying other on-farm activities to supplement their tobacco and $60 \%$ reported taking action in the past year around supplementation. Younger age and college education were positively associated with interest. College education, off-farm income, and larger farm size were associated with the number of actions taken. For perceived external barriers to diversification, use of tobacco, percent income from tobacco, lack of college education, and younger age were most strongly associated with the number of barriers. For internal barriers (personal factors), percent income from tobacco, use of tobacco, and lack of college education were most strongly associated with the number of barriers.

Conclusions-Most farmers were involved in diverse operations and expressed interest in continuing to diversify, although the breadth of diversification was narrow. Farmers noted many barriers to diversifying. If conventional production and marketing techniques are employed for non-tobacco alternatives, these alternatives may not provide the sustainable profitability that tobacco has afforded. Competition from foreign tobacco growers is the primary threat to the future of American growers and tobacco dependent communities.

(Tobacco Control 1998;7:376-382)

Keywords: tobacco farmers, crop diversification

\section{Introduction}

Tobacco use is the leading cause of premature death and disability in both developed and developing countries. ${ }^{1-6}$ Tobacco production is a key contributor to the agricultural economy of many of the same countries that experience a burden from tobacco-induced illness.
Exploring one aspect of the conflict between tobacco production and public health is the focus of the current study. In this study, we report data from extensive telephone interviews of over 1200 North Carolina tobacco farmers. To our knowledge, a survey of this size has not been implemented previously.

Between 1996 and 1998, monumental political changes occurred in the United States to promote the reduction of tobacco usage. On 20 June 1997, for example, state attorneys general announced a proposed $\$ 368$ billion tobacco settlement with tobacco companies. Likewise, many legislative bills were introduced in the 105th Congressional Session, including measures to reduce tobacco use among children, restrict tobacco advertising, raise the excise tax on tobacco products, strengthen Federal Drug Administration (FDA) regulatory measures over tobacco, and require new warnings and disclosure of additives on cigarette packs. Much of the attention in the settlement talks, and proposed legislation, focused appropriately on reducing and preventing tobacco use. Until late 1997 and early 1998, however, policymakers focused relatively little attention on tobacco farmers despite the fact that tobacco-related legislation could affect the economic livelihood of thousands of communities across the southeastern United States and of over 120000 tobacco farmers.

For instance, in the original settlement deal, there was no mention of tobacco farmers nor were growers represented at the bargaining table. In later discussions, however, farmer interests were well-represented. In a press conference held in September 1997, President Clinton made a case for considering the interests of both public health and tobacco farmers: "And finally, any tobacco legislation must protect tobacco farmers and their communities. We know that tobacco farmers are honest, hard-working people, most of whom live and work on small, family-owned farms. In some states, entire communities rely on income from the tobacco crop. Any legislation must protect these farmers, their families and their communities from loss of income. ${ }^{7}$ "

In this paper, we focus attention on questions concerning their beliefs about the future of tobacco farming and their experience with non-tobacco crop diversification. (The term 'crop diversification' is used in this paper because it is a common expression; however, crop farmers can also diversify into non-crop farm activity such as livestock and fish.) We are particularly interested in factors that predict 
the extent to which farmers were involved in diversification and their perceptions of barriers to becoming more diversified. It is important to assess the attitudes, beliefs, and behaviours of farmers since the perspective of farmers influences the policy positions taken by farmer interest groups which subsequently help set the agenda for policy discussion around tobacco control and rural development. Thus, data reported in this study can help inform policy deliberations about the possible barriers to diversification and also the factors that influence farmers' decisions to diversify their farming operations.

\section{Methods}

Data reported in this paper were from a 14 county intervention study in which seven counties were randomised to treatment and seven counties to control. To determine which counties were included in the study, we rank ordered, on the basis of pounds of flue-cured tobacco produced, all counties in North Carolina. With the exception of one county (ranked 15 th), the largest tobacco producing counties were included in the study. We dropped the 14th largest producing county and replaced it with the 15th largest producer because the former was in a different region of the state. Including the 14th largest producer would have made the intervention study logistically difficult.

A list of the tobacco farmers in these 14 counties was drawn from a list of tobacco farmers owned by a for-profit company. This company compiled the names of tobacco farmers from federal government records of tobacco quota owners as well as from proprietary information from subscribers to farm magazines and from market research studies completed by this company. The list of farmers was updated on a regular basis. The entire list from which we purchased a subset contained individuals who farmed $95 \%$ of the farmland acres in the United States.

Interviewing was completed by the University of South Carolina's Survey Research Laboratory (SRL) using a computer assisted telephone interviewing system (CATI). Interviewing began on 8 January 1997 and was completed on 1 April 1997. A pretest of the survey instrument was conducted with 31 farmers in early December 1996. As a result of this pretest, a number of changes in the structure of the survey were made.

In the initial sample design, sample elements in each of the 14 target counties were divided into three strata based on acreage farmed: (1) less than 5 acres (2.0 hectares); (2) 5-24 acres (2.0-9.7 hectares); and (3) 25 or more acres $(\geqslant 10.1$ hectares). The sample was originally drawn so that the number of cases in each strata would reflect the appropriate proportions of tobacco farmers in each county. These proportions were derived from 1992 data from the United States Department of Agriculture census. In implementing this sampling plan, two barriers were encountered: (1) the number of acres that farmers reported growing when asked about this in the interview were in some cases different from (usually larger than) the number of acres reported in the sample list, thereby resulting in an underrepresentation of the smaller strata; and (2) some of those sampled indicated that they did not directly produce tobacco-many of them leased their quota (right to grow) to other farmers.

As a result of these barriers, the design was modified so that: (1) the $<5$-acre strata was eliminated; (2) an additional sample of 1052 elements from the 5-24 acre strata was selected; and (3) in those cases where the household reported that it was not involved in tobacco farming, an attempt was made to determine if it leased its quota to others, and, if so, contact was attempted with the individuals to whom the quota was leased (44\% reported leasing its quota to others). The proportion of the sample reporting that they leased their quota to others is consistent with the trend of increased quota leasing and with 1991 data indicating that only $7 \%$ of flue-cured tobacco quota owners owned the entire quota they produced. ${ }^{8-10}$ Similarly, a recent report indicated that there are 120000 tobacco farms but over 300000 tobacco quotas. ${ }^{11}$

Each telephone number was contacted a minimum of 15 times before it was considered a non-response: the response rate was $91.2 \%$. Interviews were scheduled seven days per week, typically between the hours of $3 \mathrm{pm}$ to $10 \mathrm{pm}$, although farmers who requested interviews outside this time were accommodated. Interviews lasted on average approximately 25 minutes. Interviews were monitored periodically to make sure that questions were being asked properly and that other quality control procedures were being implemented as planned. Farmers interviewed were asked a variety of questions about their farming operations and their expectations for the future.

\section{STATISTICAL METHODS}

The key dependent variables were interest in supplementation, number of activities taken to learn about supplementation, and perceived barriers to supplementation. (We use "diversification" and "supplementation" interchangeably in this paper.) These outcomes were analysed with logistic regression for binary dependent variables and linear regression for continuous dependent variables.

Interest in supplementation was assessed with the question: "In general, are you interested or uninterested in trying other on-farm activities to supplement your tobacco income?" Those responding either "somewhat interested" or "very interested" were considered to have a "yes" response whereas those responding "somewhat uninterested" or "very uninterested" were considered to have a "no" response.

A series of seven questions concerning actions that the respondent had taken to learn about alternatives were analysed as an interval variable (a range of 0-5 actions was used since few farmers took more than five actions). The actions assessed were requested written material, attended a meeting about supplementation, attended a farm demonstration of 
supplemental crops or methods, met with an agricultural extension agent, visited another farmers' diversified operation, asked a politician to support diversification policies, and asked a lender to support changes in policies to support diversification.

Questions about the barriers farmers faced in trying to grow or raise other commodities were categorised into internal barriers (those related to the skills and interest of the individual farmer) and external barriers (those in the external environment that interfered with diversification). The individual barrier items were analysed using logistic regression. In addition, the sum of the barriers ( $0-2$ for internal barriers, $0-7$ for external barriers) were analysed using linear regression.

Univariate comparisons were made with either contingency tables (results expressed as percentages with a yes response) or logistic regression (results expressed as odds ratios with approximate $95 \%$ confidence intervals). Multiple logistic and linear regression analyses were performed to discern the association between dependent variables and possible predictors, while adjusting for other covariates. Potential explanatory variables included age of respondent (presented in 10-year intervals), percent of family gross income from tobacco sales (presented in increments of $20 \%$ change), tobacco farm size (presented in 25-acre (10.1 hectares) increments), whether the respondent uses any tobacco (yes/no), at least some college education (yes/no) and whether the respondent or spouse received any off-farm income. Independent variables that were dummy coded $(0,1)$ were variables for use of tobacco products (yes $=1$ ), at least some college education (yes $=1$ ) and whether the respondent or their spouse had any off-farm income (yes $=1$ ).

Probability values for these associations were calculated for each independent variable for both univariate models and for multivariate models. Only the univariate odds ratios with confidence intervals and univariate and multivariate $p$-values are reported here. The fit of the logistic regression models was assessed using the goodness of fit test described by
Hosmer and Lemeshow. ${ }^{12}$ These analyses rejected the null hypothesis that the fully adjusted model was a good fit for only one out of the 14 total models. The only model that showed a significant lack of fit $(\mathrm{p}<0.05)$ was the model of "Barriers: shortage of quality labor" as the response. Finding one model with a significant lack of fit is not an unexpected result when testing lack of fit on a total of 14 models.

\section{Results}

Most respondents in this study were white $(92 \%)$ and male $(92 \%)$. The mean age of respondents was $50 ; 41 \%$ had post-high school education. Most (82\%) did not work off-farm, although $44 \%$ reported that their spouse or significant other did (of these, $84 \%$ worked off-farm on a full-time basis). Nearly half the respondents $(47 \%)$ reported at least occasional use of either cigarettes or smokeless tobacco.

BELIEFS ABOUT THE FUTURE

Respondents were asked several questions about their expectations for the future. These interviews took place several months before the tobacco settlement proposal. Thus, at the time the data were collected, the settlement was not a salient news story, or a topic of general public discourse.

On the question of future intentions to grow tobacco, most farmers (84\%) did not "expect to give up tobacco farming for reasons other than retirement," although intentions to continue raising tobacco was inversely related to education $(\mathrm{p}<0.001)$ and positively related to age $(\mathrm{p}<0.001)$. Optimism about raising tobacco in the future, however, was tempered substantially when we asked farmers whether they would advise their children to raise tobacco in the future. In response to this question, 34\% reported that they would advise their children not to raise tobacco in the future and $6 \%$ reported not knowing what to advise.

These findings coincide with farmers' beliefs that the number of tobacco farms in North Carolina will decrease over the next 10 years (90\% agree or strongly agree that this will happen). Also, farmers were concerned about a variety of threats to their viability from health

Table 1 Survey responses for diversification outcomes (odds ratios and 95\% confidence intervals)

\begin{tabular}{|c|c|c|c|c|c|c|}
\hline \multirow{2}{*}{$\begin{array}{l}\text { Question } \\
\begin{array}{l}\text { Interested in other on-farm activities to supplement your tobacco } \\
\text { income }\end{array}\end{array}$} & \multirow{2}{*}{$\begin{array}{l}\begin{array}{l}\% \text { Response } \\
(n=1236)\end{array} \\
60.3\end{array}$} & Age 10 years $^{(a)}$ & \multicolumn{2}{|c|}{$\begin{array}{l}\% \text { Income from tobacco } \\
\text { (1996) }\left(20 \% \text { change }^{(b)}\right)\end{array}$} & \multicolumn{2}{|c|}{$\begin{array}{l}\text { Farm size } 25 \text { acre } \\
\text { change } e^{(c)}\end{array}$} \\
\hline & & $0.772^{\star \star}+(0.700-0.852)$ & 0.987 & $(0.911-1.068)$ & 0.997 & $(0.942-1.055)$ \\
\hline $\begin{array}{l}\text { In past year, applied for loans, grants to support efforts to } \\
\text { supplement your tobacco income } \\
\text { Any "internal" barriers }\end{array}$ & 26.0 & $0.769^{\star \star}+(0.688-0.859)$ & $1.100^{\star}$ & $(1.009-1.199)$ & $1.145^{\star \star}$ & $(1.077-1.216)$ \\
\hline Don't have an interest in growing or raising anything except tobacco & 35.5 & $1.221^{\star \star}+(1.106-1.348)$ & 1.039 & $(0.959-1.125)$ & 0.986 & $(0.931-1.045)$ \\
\hline $\begin{array}{l}\text { Need additional skills to grow or raise something other than tobacco } \\
\text { Any "external" barriers }\end{array}$ & 48.8 & $1.003(0.913-1.101)$ & 1.035 & $(0.958-1.118)$ & 1.043 & $(0.986-1.102)$ \\
\hline No places to sell new products & 66.6 & $0.879^{\star} \quad(0.795-0.972)$ & $1.184^{\star \star}$ & $(1.085-1.292)$ & 1.061 & $(0.999-1.126)$ \\
\hline Lack of capital for new business ventures & 64.2 & $(0.848-1.033)$ & $1.087 \dagger$ & $(1.000-1.181)$ & 0.964 & $(0.911-1.021)$ \\
\hline Lack of low-interest loans, grants for new business ventures & 63.3 & $0.775^{\star \star}+(0.701-0.856)$ & 0.981 & $(0.903-1.065)$ & 1.014 & $(0.958-1.074)$ \\
\hline Low supply of quality labour & 82.4 & $0.924 \quad(0.814-1.048)$ & 1.004 & $(0.903-1.117)$ & $0.918^{\star} \dagger$ & $(0.856-0.983)$ \\
\hline Lack of processing plants near & 72.2 & $0.768^{\star \star}+(0.690-0.856)$ & 1.068 & $(0.975-1.171)$ & 1.040 & $(0.976-1.107)$ \\
\hline Lack of support from community, regional, or state leaders & 48.7 & $(0.895-1.079)$ & 1.036 & $(0.959-1.120)$ & 0.948 & $(0.897-1.003)$ \\
\hline Nothing is as profitable as tobacco & 87.7 & $(0.798-1.073)$ & 1.012 & $(0.894-1.146)$ & $1.157^{\star \star} \dagger$ & $(1.049-1.276)$ \\
\hline
\end{tabular}

${ }^{\star} \mathrm{p}<0.05$, unadjusted logistic regression model; ${ }^{\star \star} \mathrm{p}<0.01$, unadjusted logistic regression model; $\nmid \mathrm{p}<0.05$, adjusted for all other factors in logistic regression model.

${ }^{(a)}$ Age was included in models as a continuous variable; odds ratios are expressed in terms of 10 -year increments.

(b) \% Income from tobacco was included in models as a continuous variable; odds ratios are expressed in terms of $20 \%$ increments.

${ }^{(c)}$ Farm size was included in models as a continuous variable; odds ratios are expressed in terms of 25 -acre (10.1 hectare) change.

(d) Reference category $=$ no. 


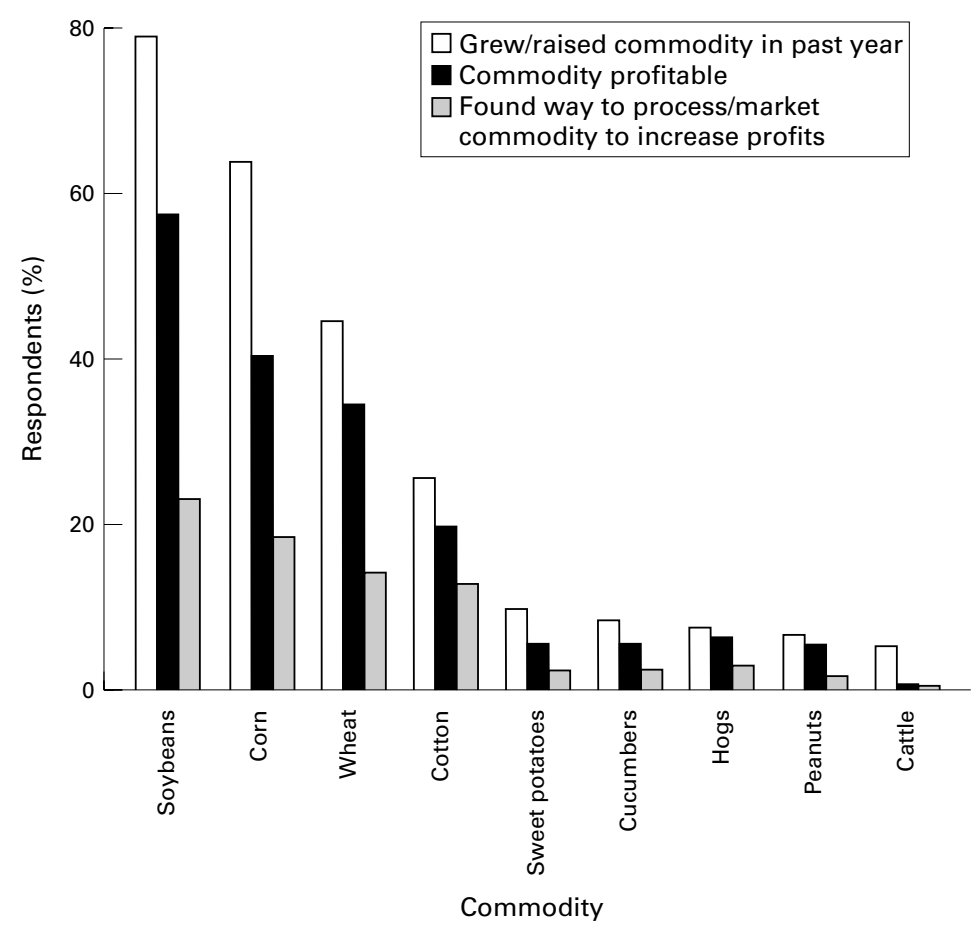

Experience with non-tobacco commodities.

groups and tobacco manufacturers. In response to questions about these threats, most farmers believed that public health and medical groups wanted to put them out of business ( $84 \%$ agreed or strongly agreed), that tobacco companies were interested in expanding foreign tobacco growing and manufacturing operations $(81 \%$ agreed or strongly agreed), and that the assistance provided by tobacco companies to foreign growers poses a threat to the future of American tobacco farmers ( $81 \%$ agreed or strongly agreed).

We also asked farmers whether they would continue growing tobacco at different prices/pound received on the warehouse floor. By way of background, tobacco farmers in North Carolina receive on average about $\$ 1.80$ per pound ( $\$ 0.82$ per $\mathrm{kg}$ ) for their flue-cured tobacco. In contrast, flue-cured leaf grown in Zimbabwe is sold for about $\$ 1.33$ per pound $(\$ 0.60$ per $\mathrm{kg}$ ) and in Brazil for about 97 cents

Table 1 continued

\begin{tabular}{|c|c|c|c|}
\hline \multicolumn{2}{|c|}{ Use any tobacco? Yes vs no ${ }^{(d)}$} & Any college? Yes vs no ${ }^{(d)}$ & Off-farm income? Yes vs no ${ }^{(d)}$ \\
\hline 1.077 & $(0.854-1.360)$ & $1.563^{\star \star}+(1.231-1.984)$ & $1.256(1.000-1.578)$ \\
\hline 1.179 & $(0.911-1.526)$ & $(0.812-1.368)$ & $1.335^{\star}(1.033-1.725)$ \\
\hline 1.153 & $(0.909-1.462)$ & $0.570^{\star \star}+(0.446-0.729)$ & $1.044 \quad(0.827-1.318)$ \\
\hline 1.193 & $(0.950-1.498)$ & $0.766^{\star} \quad(0.608-0.964)$ & $1.301^{\star}(1.040-1.627)$ \\
\hline $1.689^{\star \star} \dagger$ & $(1.320-2.160)$ & $(0.769-1.254)$ & $1.100 \quad(0.868-1.393)$ \\
\hline $1.420^{\star \star}$ & $(1.117-1.806)$ & $0.626^{\star \star}+(0.492-0.796)$ & $1.112(0.881-1.403)$ \\
\hline $1.660^{\star \star}+$ & $(1.305-2.111)$ & $(0.626-1.011)$ & $1.412^{\star \star}(1.120-1.781)$ \\
\hline $1.515^{\star} \dagger$ & $(1.106-2.076)$ & $(0.792-1.483)$ & $1.111 \quad(0.829-1.488)$ \\
\hline $1.685^{\star \star} \dagger$ & $(1.295-2.191)$ & $(0.882-1.488)$ & $1.412^{\star \star(1.100-1.813)}$ \\
\hline $1.323^{\star}$ & $(1.054-1.662)$ & $0.584^{\star \star}+(0.463-0.736)$ & $1.106 \quad(0.885-1.383)$ \\
\hline 1.319 & $(0.914-1.903)$ & $(0.944-2.000)$ & $1.049 \quad(0.747-1.473)$ \\
\hline
\end{tabular}

per pound $(\$ 0.44 / \mathrm{kg}) .^{13}$ Most respondents indicated that they would continue raising tobacco if they received $\$ 2.00$ per pound $(\$ 0.91 / \mathrm{kg})(99 \%)$ or $\$ 1.75$ per pound $(\$ 0.79 / \mathrm{kg})(89 \%)$. The proportion agreeing to raise tobacco, however, dropped precipitously at lower prices: $\$ 1.50(\$ 0.68 / \mathrm{kg})(28 \%), \$ 1.25$ $(\$ 0.57 / \mathrm{kg})(4 \%), \$ 1.00(\$ 0.45)(2 \%), \$ 0.75$ $(\$ 0.34 / \mathrm{kg})(0.4 \%)$.

EXPERIENCE WITH AND ATTITUDES TOWARD DIVERSIFICATION

We asked respondents a series of detailed questions about their experience with the production of commodities other than tobacco. Most farmers (95\%) reported growing or raising a commodity other than tobacco on their farm in the past year. Regarding farmers interest in "trying other on-farm activities to supplement their tobacco income," $28 \%$ reported being "very interested" and 32\% reported being "somewhat interested." Likewise, $60 \%$ of respondents reported that they or a member of their family who lived on the farm took action in the past year to "specifically learn more about supplementing [their] tobacco income". Actions included such things as requesting written material about supplementing their tobacco income, attending a meeting about supplementation, and attending a farm demonstration of supplemental crops or methods. Likewise, we asked farmers whether in the past year they had "applied for loans, grants, or other money to support efforts to supplement their tobacco income": $26 \%$ reported doing so.

The figure provides data on the most frequently mentioned non-tobacco commodities grown or raised by the 1236 farmer respondents. The nine commodities listed on the figure represent $90 \%$ of all the non-tobacco commodities grown or raised by respondents. The first bar indicates the percentage of respondents who grew or raised the commodity in the past year. The second bar indicates the percentage of respondents indicating whether the commodity was raised profitably. The third bar indicates the percentage of respondents who have found a way to process or market the commodity to increase their profits (adding value to the enterprise). The data illustrate that field crops are the most widely grown non-tobacco commodity, although this probably reflects in part the need to rotate tobacco with other field crops so as not to deplete the soil. Most farmers report that non-tobacco commodities are profitable, although few have found ways to process or market these commodities in ways that increase their value and profitability.

In addition to the nine commodities listed in the figure, 333 attempts were made to grow or raise other non-tobacco commodities in the past year. These commodities included a variety of other types of livestock, grains, and fruits and vegetables. Of the total of 333 attempts, $199(60 \%)$ were reported as profitable. Of these, $114(34 \%)$ reported to have found ways to process or market these commodities to add value. Across all of the 
non-tobacco supplements mentioned by respondents, the mean number of enterprises attempted was 2.8 (SD 1.3; median $=3$; range: $0-5)$.

We also asked a question about farmers awareness of other farmers in their county who are making profits from the production of nontobacco commodities. In response to the question: "In the past year, do you know tobacco farmers in your county who have tried new agricultural activities other than tobacco that were profitable," $50 \%$ responded "yes."

Respondents were also specifically asked about nine barriers, two internal and seven external, that might interfere with their ability to supplement or replace their tobacco income with other on-farm ventures. As noted in tables 1 and 2, these barriers were salient to many of the farmers interviewed. Table 2 provides descriptive data by subgroup (for example, farm size, tobacco use, education, off-farm income, age) for questions on barriers to supplementation, stated interest in supplementation, and actions to seek loans or grants to supplement tobacco income. Table 1 presents the odds ratios and confidence intervals for unadjusted and adjusted logistic regression analyses for the same independent and dependent variables reported in table 2 .

We also ran multiple linear regression analyses for indices with interval level outcomes. For the barriers questions, we regressed the number of barriers ( $0-2$ for internal barriers, 0-7 for external barriers) against the same independent variables noted in table 1 . For the internal barriers analysis (mean $=1.4$, SD 0.7), tobacco use $(\beta=0.20, p<0.0001)$, percent income from tobacco $(\beta=0.28$, $\mathrm{p}<0.0007)$, and lack of college education $(\beta=$ $-0.13, p<0.01)$ were significant predictors of the number of internal barriers mentioned (multiple $r^{2}=0.048$ ). For the external barriers analysis (mean $=5.0, \mathrm{SD} 1.7$ ), use of tobacco $(\beta=0.52, p<0.0001)$, percent income from tobacco $(\beta=0.39, p<0.04)$, lack of college education $(\beta=-0.30, \mathrm{p}<0.014)$, and age $(\beta=$ $-0.13, p<0.02)$ were significant predictors of the number of external barriers mentioned (multiple $r^{2}=0.048$ ).

As noted previously, farmers were asked a series of seven questions about activities they had taken to learn about diversification. In a multiple linear regression that predicted the number of activities taken (range: $0-5$, mean $=$ 1.4, SD 1.6)) and using the same independent variables used in the logistic regression analyses reported in table 1 , we found that having a college education $(\beta=0.408$, $\mathrm{p}<0.0004)$, larger farm $(\beta=0.004, \mathrm{p}<0.0008)$, and off-farm income $(\beta=0.25, \mathrm{p}<0.03)$ were significant predictors (multiple $r^{2}=039$ ).

\section{Conclusions}

In this study, we found that most North Carolina tobacco farmers living in 14 counties with high tobacco production expressed interest in supplementing their tobacco income with nontobacco commodities. Likewise, the majority have taken at least one action in the past year to learn more about supplementation. A high percentage of farmers reported growing or raising non-tobacco commodities, although a relatively smaller percentage reported profitability from these non-tobacco enterprises and very few found processing or marketing innovations that added value and profitability. The fact remains that as a whole, no other commodities can generate the profits per acre that tobacco produces. ${ }^{14}$ There are case studies of individual tobacco growers makingcomparable profits growing or raising other commodities ${ }^{15-19}$ but without huge investments in the rural infrastructure of the tobacco south, the scale of these alternatives is insufficient to entirely replace tobacco. ${ }^{9}$

Here, we summarise some of the key findings of this study, focusing primarily on the significant findings from the adjusted multivariate logistic and linear regression models. For interest in diversification, younger

Table 2 Survey responses for diversification outcomes (\% response)

\begin{tabular}{|c|c|c|c|c|c|c|c|c|c|c|c|c|}
\hline & \multirow[b]{2}{*}{$\%$ Response } & \multicolumn{2}{|c|}{ Farm size } & \multicolumn{2}{|c|}{$\begin{array}{l}\text { Use any } \\
\text { tobacco? }\end{array}$} & \multicolumn{2}{|c|}{ Any college? } & \multicolumn{2}{|c|}{$\begin{array}{l}\text { Off-farm } \\
\text { income? }\end{array}$} & \multicolumn{3}{|c|}{ Age category } \\
\hline & & $<24$ & $\geqslant 24$ & No & Yes & No & Yes & No & Yes & $<40$ & $40-60$ & $>60$ \\
\hline & $\mathrm{n}=1236$ & 306 & 863 & 638 & 558 & 692 & 502 & 597 & 639 & 282 & 629 & 279 \\
\hline $\begin{array}{l}\text { Interested in other on-farm activities to } \\
\text { supplement your tobacco income }\end{array}$ & 60.3 & 56.5 & 61.8 & 59.9 & 61.6 & 56.2 & 66.7 & 57.5 & 62.9 & 68.1 & 63.1 & 47.7 \\
\hline $\begin{array}{l}\text { Any activities to learn more about } \\
\text { supplementing your tobacco income }\end{array}$ & 60.1 & 52.9 & 63.4 & 59.8 & 60.6 & 57.3 & 64.0 & 58.5 & 61.5 & 56.5 & 61.3 & 61.3 \\
\hline $\begin{array}{l}\text { In past year, applied for loans, grants to } \\
\text { support efforts to supplement your } \\
\text { tobacco income }\end{array}$ & & & & & & & & & & & & \\
\hline $\begin{array}{l}\text { tobacco income } \\
\text { Any "internal" barriers }\end{array}$ & $\begin{array}{l}26.0 \\
62.5\end{array}$ & $\begin{array}{l}17.0 \\
62.4\end{array}$ & $\begin{array}{l}29.0 \\
62.1\end{array}$ & $\begin{array}{l}24.8 \\
60.0\end{array}$ & $\begin{array}{l}28.0 \\
65.9\end{array}$ & $\begin{array}{l}25.9 \\
66.9\end{array}$ & $\begin{array}{l}26.9 \\
57.2\end{array}$ & $\begin{array}{l}23.1 \\
59.3\end{array}$ & $\begin{array}{l}28.6 \\
65.4\end{array}$ & $\begin{array}{l}32.6 \\
58.5\end{array}$ & $\begin{array}{l}28.5 \\
64.2\end{array}$ & $\begin{array}{l}15.4 \\
64.2\end{array}$ \\
\hline $\begin{array}{l}\text { Don't have an interest in growing or } \\
\text { raising anything except tobacco }\end{array}$ & 35.5 & 37.6 & 34.4 & 34.0 & 37.3 & 40.9 & 28.3 & 35.0 & 36.0 & 29.1 & 35.3 & 42.7 \\
\hline $\begin{array}{l}\text { Need additional skills to grow or raise } \\
\text { something other than tobacco }\end{array}$ & 48.8 & 45.8 & 49.0 & 47.0 & 51.4 & 51.9 & 45.2 & 45.4 & 52.0 & 48.9 & 50.9 & 45.2 \\
\hline Any "external" barriers & 95.2 & 95.1 & 95.1 & 95.3 & 98.0 & 96.1 & 97.2 & 95.0 & 95.5 & 96.5 & 97.0 & 95.7 \\
\hline No places to sell new products & 66.6 & 65.0 & 67.1 & 61.9 & 73.3 & 67.3 & 66.9 & 65.5 & 67.6 & 70.6 & 68.5 & 62.0 \\
\hline Lack of capital for new business ventures & 64.2 & 65.4 & 64.4 & 61.4 & 69.4 & 69.7 & 59.0 & 63.0 & 65.4 & 65.6 & 67.4 & 59.9 \\
\hline $\begin{array}{l}\text { Lack of low-interest loans, grants for } \\
\text { new business ventures }\end{array}$ & 63.3 & 63.7 & 63.0 & 58.9 & 70.4 & 66.6 & 61.4 & 59.1 & 67.1 & 70.9 & 67.4 & 50.9 \\
\hline Low supply of quality labour & 82.4 & 83.7 & 82.2 & 81.2 & 86.7 & 83.4 & 84.5 & 81.6 & 83.1 & 84.8 & 85.1 & 79.6 \\
\hline $\begin{array}{l}\text { Lack of processing plants near farming } \\
\text { communities }\end{array}$ & 72.2 & 69.9 & 72.7 & 68.7 & 78.7 & 72.3 & 74.9 & 68.7 & 75.6 & 78.4 & 77.1 & 60.9 \\
\hline $\begin{array}{l}\text { Lack of support from community, } \\
\text { regional, or state leaders }\end{array}$ & 48.7 & 50.0 & 48.3 & 46.2 & 53.2 & 55.2 & 41.8 & 47.4 & 49.9 & 49.3 & 51.5 & 46.2 \\
\hline Nothing is as profitable as tobacco & 87.7 & 84.3 & 89.0 & 87.6 & 90.3 & 87.6 & 90.6 & 87.4 & 87.9 & 90.1 & 88.7 & 87.8 \\
\hline
\end{tabular}


age and college education were positively associated with interest. For taking action around diversification, college education, off-farm income, and larger farm size were significant predictors of the number of actions taken. For applying for loans, younger age was the only significant predictor. For the questions about barriers to diversification, there are too many questions to summarise succinctly. However, looking across barriers, it is evident that for external barriers, younger age, use of tobacco, and lack of college education were most strongly associated with reporting barriers. For internal barriers, older age and lack of college education were most strongly associated with reporting barriers.

An overall impression of these data might be that younger, more educated farmers who do not personally use tobacco are more likely to be interested in diversification and perceive fewer internal barriers to diversifying (such as their own skills and interests) and more external barriers (lack of low interest loans or grants and processing plants, for example) than other subgroups. It may be that older growers are more likely to be committed to maintaining the status quo, or simply hanging on, until they retire. Likewise, less educated growers might have fewer internal resources and skills to adapt to major changes in the status quo and thus are more concerned about their ability to succeed in a more diversified economy that might require new knowledge and skills to succeed. The fact that use of tobacco was significantly related to perceiving barriers to diversification was a surprise initially.

Upon reflection, however, we interpreted this finding as suggesting that individuals who are involved in both the production and personal use of tobacco have a different set of attitudes and beliefs as compared with those who are involved in production alone. Personal use of tobacco may well result in a higher level of commitment to, defensiveness about, or psychological investment in, tobacco. That said, however, we did not find that personal use of tobacco influenced being interested in diversification or engaging in actions to learn more about diversification.

Policies that promote rural development, agricultural sustainability, and diversification are ultimately good medicine for the American tobacco grower. Indeed, the future of American tobacco production is uncertain in light of projected decreasing worldwide demand for American grown tobacco, due to its higher cost relative to tobacco produced by other countries. In addition, changes in the Tobacco Price Support Program that might occur as a result of a tobacco settlement or other legislation could put many smaller American growers out of business. That said, this is not a new issue-large-scale change in tobacco farming has been occurring for many decades. ${ }^{11}$ In the southern United States where tobacco is grown, its importance to the economy has declined over time, though it still remains important. In North Carolina, for example, the contribution of tobacco to the state's agricultural economy has declined from nearly $60 \%$ of total farm income in 1950 to $20 \%$ in $1992 .{ }^{20}$ The contribution of tobacco to the gross state product declined from $11.3 \%$ in 1963 to $7.8 \%$ in $1993 .{ }^{20}$ Likewise, about $1 \%$ of the employed population in North Carolina work directly in tobacco farming, processing, and manufacturing sectors and another 1\% own tobacco quota that generates rent or lease income. ${ }^{20}$ These data are consistent with the trend of declining tobacco acreage and production-from the late 1950 s to the early 1990s, tobacco production in North Carolina declined nearly $30 \%$ and tobacco acreage declined over $42 \%{ }^{20}$ Across the entire tobacco region, between 1964 and 1992, the number of tobacco farms has decreased $62 \%$ (from $330000124000) .{ }^{11}$ From 1982 to 1992 , the last 10-year period for which data are available, the number of tobacco farms declined by $50000 .{ }^{11}$ And, from 1997 to 1998 , it is projected that the effective flue-cured tobacco quota will decrease by approximately $20 \%{ }^{21}$

Foreign tobacco production is the primary threat to American growers: over the past 25 years, the amount of imported tobacco used in cigarettes manufactured in the United States has increased from $2 \%$ to more than $33 \%{ }^{20}$ and foreign countries have invested substantial resources in tobacco production to meet the unfortunate increase in worldwide demand. In Zimbabwe alone, land used for tobacco production was expected to increase over $17 \%$ between 1996 and $1997 . .^{22}$ As a result, American tobacco growers will experience increasing pressure to supplement their tobacco income with other enterprises, or quit farming tobacco altogether. A survey of tobacco farmers in the southeast found that $51 \%$ were "interested in trying other on-farm ventures to supplement tobacco income". ${ }^{23}$ Data reported in the current study are consistent with this finding as over $60 \%$ of North Carolina farmers reported being interested in supplementation.

Building political support for an investment in sustaining rural communities, perhaps through an increase in excise taxes on tobacco with earmarking for rural development and agricultural diversification, would be an important step in this regard. Until 1997, this seemed an unlikely scenario. Indeed, one reason why policymakers and health professionals have historically paid little attention to tobacco farmers may be a lack of knowledge about tobacco farmers and tobacco-dependent communities. $^{24}$ The United States tobacco price support and production control programme, for example, is complex and difficult to understand. ${ }^{10}$ Moreover, health professionals have been disturbed by the fact that tobacco farmers and tobacco manufacturers have combined political forces at federal, state, and local levels to resist strong, pro-health, tobacco-related legislation.

In the current policy environment for tobacco control, however, the interests of tobacco farmers and those of the tobacco manufacturers are not necessarily the same. In response to perceived threats by tobacco growers from a proposed tobacco settlement and a 
willingness of a small group of health professionals to establish relationships with growers and grower groups, an unparalleled collaboration designed to reduce tobacco consumption and promote sustainability in rural communities formed. ${ }^{25}$ This collaboration, spearheaded initially by the Southern Tobacco Communities Project, resulted in articulation of "core principles" to which growers, health professionals and community organisations signed (signatories included such organisations as the American Public Health Association, Americans for Nonsmokers' Rights, American College of Cardiology, Burley Tobacco Growers Cooperative, Inc., Flue-Cured Tobacco Stabilization Corporation, National Black Farmers Association, among many others). The core principles included health goals (such as FDA regulatory authority) and agricultural goals (for example, maintaining the Tobacco Price Support Program at no taxpayer cost). These efforts, combined with public support for policies that promote public health and protect rural farming communities historically dependent upon tobacco income, ${ }^{26}$ are indicative of new opportunities for collaboration between public health and agricultural organisations. There are signs that this collaboration, combined with the unwillingness of tobacco companies to include farmer interests in the initial June 1997 tobacco settlement altered the historically strong relationship between tobacco manufacturers and tobacco growers. In addition, the fact that manufacturers and leaf dealers are increasingly purchasing less American tobacco has made American growers resentful and suspicious. Whatever the outcome of current tobacco policy negotiations, it is clear that in the absence of support from growers, the political power of manufacturers will be reduced.

Data reported in our study of over 1200 North Carolina tobacco farmers can help inform current and future policy debates about tobacco control. In particular, it provides a perspective from tobacco farmers themselves about factors related to their interest in and ability to diversify their farming operations so as to become less dependent on tobacco. On the topic of diversification, the data are mixed. On the one hand, most farmers are involved in diverse operations expressed interest in continuing to diversify, although we found that the breadth of diversification was rather narrow. Farmers noted many barriers to successfully diversifying, however, and whether non-tobacco commodities can ultimately provide sustainable profitability is a question worthy of additional study. Indeed, regardless of whether there is a tobacco settlement or other legislation that changes the nature and profitability of tobacco production, the reality is that competition from foreign tobacco growers, who have been provided assistance and resources from American tobacco manufacturers, is the primary threat to the future of American growers and tobacco dependent communities. Meanwhile, many millions of tobacco users throughout the world die prematurely each day. As public health professionals, we believe that it is important to both eliminate tobacco-induced disease and, through diversification, promote the sustainability, and health, of thousands of rural communities historically dependent upon tobacco income.

This study was supported by grant NIH RO1 CA67838-02 from the National Cancer Institute.

1 Slama K, ed. Tobacco and health. Proceedings of the ninth world conference on tobacco and health, 10-14 October 1994. New conference on tobacco and heal
York: Plenum Press, 1995.

2 US Department of Health and Human Services. Reducing the health consequences of smoking: 25 years of progress. A report of the Surgeon General, 1989. Rockville, Maryland: Public Health Service, Centers for Disease Control, Office on Smoking and Health, 1989. (DHHS Publication No (CDC) 89-8411.)

3 US Department of Health and Human Services. Smoking and health, a national status report: a report to Congress, 2 nd ed. Rockville, Maryland: Centers for Disease Control, Office on Smoking and Health, 1990. (DHHS Publication No (CDC) 87-8396.)

4 US Department of Health and Human Services. Smoking and health in the Americas: a 1992 report of the Surgeon General in collaboration with the Pan American Health Organizaon Smoking and Health, 1992. (DHHS Publication No (CDC) 92-8419.)

5 US Department of Health and Human Services. Preventing tobacco use among young people. A report of the Surgeon Gentobacco use among young people. A report of the Surgeon Gen-
eral, 1994. Atlanta, Georgia: Public Health Service, Centeral, 1994. Atlanta, Georgia: Public Health Service, Centers for Disease Control and Prevention, Office on Smoking and Health, 1994. (US Government

cation No S/N 017-001-00491-0.)
6 World Health Organisation. Action plan on tobacco or health for 1995-1999. Kuala Lumpur, Malaysia: WHO Regional Office for the Western Pacific, 1994.

7 Clinton WJ. Remarks by the President on tobacco settlement review. Office of the Press Secretary, The Oval Office: The White House, 1997.

8 Clauson AL, Grise VN. Flue-cured tobacco farming: two decades of change. US Department of Agriculture: Economic Research Service, 1994.

9 Altman DG, Goldstein AO. The federal tobacco price support program and public health. Chapel Hill, North Carolina: Center for the Study of the American South, University of North Carolina, Chapel Hill, 1998.

10 Zhang P, Husten C. Impact of the Tobacco Price Support Program on tobacco control in the United States. Tobacco Program on tobacco co

11 Gale F. Economic structure of tobacco-growing regions. Washington, DC: US Department of Agriculture, 1998.

12 Hosmer DW, Lemeshow S. Applied logistic regression. New York City: Wiley, 1989.

13 Williams B. Tobacco market sagging: with a tobacco settlement in the wind, leaf prices dip at a particularly unfortunate time. Raleigh (North Carolina) News and Observer 1997 Sep 27.

14 Yahres MV. Tobacco-the Virginia legislative view. Chapel Hill, North Carolina: Center for the Study of the American South, 1998.

15 Pack T. Speaker tells Kentucky farmers 'vegetables are our friend'. Herald-Leader (Lexington, Kentucky) 1996 Jan 19.

16 Pack T. Kentucky growers talk sustainable agriculture, alternatives to tobacco. Herald-Leader (City?, Kentucky?) 1996 Jan 21.

17 Community Farm Alliance. Cultivating America's family farms. Berea, Kentucky: Community Farm Alliance, 1994.

18 Arledge B, Hamilton H, Altman D. Tobacco diversification efforts: personal stories. Berea, Kentucky: Center for Sustainable Systems, 1995 .

19 Carlton C. Beyond tobacco: with trouble ahead, some Kentucky farmers focus on array of alternatives. Lexington Herald-Leader 1994 Sep 11:A1.

20 O'Connor T. How important is tobacco in North Carolina? North Carolina Med $\mathcal{f}$ 1995;56:28-32.

21 Capehart T. Tobacco situation and outlook report. Washington, DC: US Department of Agriculture, 1998.

22 Anon. More land for growing tobacco in Zimbabwe. Tobacco Reporter 1997;124:20.

23 Altman DG, Levine DW, Howard G, et al. Tobacco farmers and diversification: opportunities and barriers. Tobacco Control 1996;5:192-8.

24 Altman DG. A view from the fields. North Carolina Med 7 1995;56:37-8.

25 Reeves R. Virginia Tobacco Communities Project: a search for common ground. Chapel Hill, North Carolina: Center for the Study of the American South, 1998

26 Altman DG, Levine DW, Howard G, et al. Tobacco farming and public health: attitudes of the general public and farmers. F Soc Issues 1997;53:113-28. 